\title{
PERLINDUNGAN HUKUM BAGI KONSUMEN PENGGUNA KOSMETIK YANG DIJUAL MELALUI MEDIA SOSIAL
}

\author{
${ }^{1}$ Hanny Delpyra, ${ }^{2}$ Marlia Sastro , ${ }^{2}$ Sofyan Jafar
}

\begin{abstract}
Legal protection for consumers who use cosmetics sold through social media based on Article 2 of Law No. 8 of 1999 on Consumer Protection states that, consumer protection is held as a joint venture based on five relavan principles while paying attention to the efficacy and usefulness for the parties who must perform the rights and obligations that have been determined. Along with the development of technology offerings through social media selling goods to consumers through the internet network, one of them is cosmetic products. In Article 9 of Law No. 11 of 2008 concerning Information and Electronic Transactions states that every business person must provide clear information related to the products offered. This study aims to find out and explain about legal protection for consumers against the purchase of cosmetic products through social media as well as legal consequences for businesses that have harmed consumers in the purchase of cosmetic products through social media. This research method uses normative juridical research method with statutory approach. The nature of this thesis research is descriptive research using primary legal data in the form of Law No. 8 of 1999 on Consumer Protection and Law No. 11 of 2008 on Information and Electronic Transactions, as well as secondary and tertiary legal data. Based on the results of the study that legal protection for consumers against the purchase of cosmetic products through social media has not been fully fulfilled and protected in accordance with consumer protection laws. This is due to the lack of awareness of businesses towards the fulfillment of consumer rights and obligations in transactions through social media. Thus the legal consequences for businesses that have harmed consumers must pay compensation to consumers. It is expected that businesses should pay proper attention to the rights and obligations of businesses in offering cosmetic products through social media which is basically stipulated in the provisions of consumer protection laws and consumers must also be wiser and careful in buying cosmetic product offerings offered by businesses on social media so that no unwanted things happen to consumers.
\end{abstract}

Keywords: Legal Protection, Consumer, Social Media. 


\section{PENDAHULUAN}

Seiring dengan berkembangnya teknologi yang diciptakan, kebutuhan manusia untuk memudahkan hidup dari yang sebelumnya. ${ }^{1}$ Kegiatan teknologi dapat dimanfaatkan sebagai sarana untuk melakukan jual beli di media sosial. Jual beli yang dilakukan melalui media sosial menawarkan berbagai macam produk yang dilakukan oleh pelaku usaha terhadap konsumen. Penawaran melalui media sosial berjalan melalui jaringan internet, yang menjadi salah satu media yang efektif bagi pelaku usaha untuk memperkenalkan dan menjual barang ke konsumen dari seluruh dunia, pemasaran melalui media sosial diatur dalam Undang-Undang Nomor 11 Tahun 2008 tentang Informasi dan Transaksi Elektronik (selanjutnya disebut UUITE).

Perlindungan hukum merupakan segala upaya pemenuhan hak dan pemberian bantuan untuk memberikan rasa aman kepada saksi dan/atau korban, perlindungan hukum korban kejahatan sebagai bagian dari perlindungan masyarakat, dapat diwujudkan dalam berbagai bentuk, seperti melalui pemberian restitusi, kompensasi, pelayanan medis, dan bantuan hukum. ${ }^{2}$

Menurut Philipus M. Hadjon ${ }^{3}$ berpendapat bahwa perlindungan hukum adalah perlindungan akan harkat dan martabat, serta pengakuan terhadap hak-hak asasi manusia yang dimiliki oleh subyek hukum berdasarkan ketentuan hukum dari kesewenangan atau sebagai kumpulan peraturan atau kaidah yang akan dapat melindungi suatu hal dari hal lainnya. Berkaitan dengan konsumen, berarti hukum memberikan perlindungan terhadap hak-hak pelanggan dari sesuatu yang mengakibatkan tidak terpenuhinya hak-hak tersebut. Kegiatan bisnis yang sehat terdapat keseimbangan perlindungan hukum antara konsumen dengan produsen. Lebih-lebih jika produk yang terbatas, produsen dapat menyalahgunakan posisinya yang monopolistis, hal itu tentu saja akan merugikan konsumen. ${ }^{4}$

Perlindungan konsumen ini merupakan jaminan yang seharusnya didapatkan oleh para konsumen atas setiap produk bahan makanan yang dibeli dari produsen atau pelaku usaha. ${ }^{5}$ Perlindungan konsumen tidak saja terhadap barang-barang berkualitas rendah, akan tetapi juga terhadap barang-barang yang membahayakan kehidupan masyarakat. ${ }^{6}$ Kerugian-kerugian yang dialami oleh konsumen tersebut dapat timbul sebagai akibat dari adanya hubungan hukum perjanjian antara pelaku usaha dengan konsumen, maupun akibat dari adanya perbuatan melanggar hukum yang dilakukan oleh pelaku usaha.

Pasal 1 angka (1) Undang-Undang Nomor 8 Tahun 1999 tentang Pelindungan Konsumen (selanjutnya disebut UUPK) mendefinisikan perlindungan konsumen merupakan segala upaya yang menjamin adanya kepastian hukum untuk memberi perlindungan kepada konsumen. Kemudian Pasal 1 angka (3) mendefinisikan pelaku usaha "setiap orang perseorangan atau badan usaha, baik yang berbentuk badan hukum maupun bukan badan hukum yang didirikan dan berkedudukan atau melakukan kegiatan dalam wilayah hukum negara Republik Indonesia, baik sendiri maupun bersama-sama melalui perjanjian penyelenggaraan kegiatan usaha dalam berbagai bidang ekonomi”. Sehingga akan memudahkan konsumen untuk

${ }^{1}$ Hikmahanto Junawa, Hukum Ekonomi dan Hukum Internasional, Lentara Hati, Jakarta, 2002, hlm.23.

2Soerjono Soekanto, Pengantar Penelitian Hukum, UI Press, Jakarta, 1984, hlm. 133.

3Phillipus M. Hadjon, Perlindungan Hukum Bagi Rakyat Indonesia, Bina Ilmu, Surabaya, 1987, hlm. 25 .

4Ahmadi Miru, Prinsip-prinsip Perlindungan Hukum Bagi Konsumen Di Indonesia, PT RajaGrafindo Persada, Jakarta, 2011, hlm. 1.

5Rosmawati, Pokok-pokok Hukum Perlindungan Konsumen, Depok, 2018, hlm. 1.

6Ibid, hlm. 6. 
menentukan kepada siapa ia akan mengajukan tuntutan jika ia diragukan akibat penggunaan produk. $^{7}$

Sebagaimana diatur dalam Pasal 1 ayat (1) Peraturan Mentri Kesehatan Republik Indonesia Nomor 1175/MENKES/VIII/2010 tentang izin produksi kosmetika, yang dimaksud dengan kosmetik ialah: bahan atau sediaan yang dimaksudkan untuk digunakan pada bagian luar tubuh manusia (epidermis, rambut, kuku, bibir dan organ genital bagiar luar) atau gigi atau mukosa mulut terutama untuk membersihkan, mewangikan, mengubah penampilan dan atau memperbaiki bau badan atau melindungi atau memelihara tubuh pada kondisi baik. Dalam hal ini kesehatan fisik terhadap konsumen dalam menggunakan kosmetik di Indonesia sangatlah penting. Kesehatan fisik yang dimaksud adalah kesehatan konsumen yang berhubungan dengan keamanan dan keselamatan tubuh. ${ }^{8}$ Kesehatan fisik konsumen dapat terganggu kalau suatu perolehan barang atau jasa malah menimbulkan kerugian berupa gangguan kesehatan badan atau ancaman pada keselamatan jiwanya.

Maraknya temuan kosmetik karena adanya celah yang dimanfaatkan para pelaku kejahatan dengan mengedarkan produk mereka secara media sosial dan masih tingginya permintaan masyarakat terhadap kosmetik murah. ${ }^{9}$ Era perdagangan bebas seperti saat ini banyak kosmetik yang beredar di pasaran dengan berbagai jenis merek, harga, dan kualitas. Keinginan wanita untuk tampil cantik banyak dimanfaatkan oleh pelaku usaha yang tidak bertanggung jawab untuk meraih keuntungan lebih dengan memproduksi atau memperdagangkan kosmetik yang tidak memenuhi persyaratan untuk diedarkan. Oleh karena itu, pemberlakuan suatu peraturan perundang-undangan, pada dasarnya dimaksudkan untuk merubah atau mengarahkan perilaku dan/atau situasi tertentu, dari yang semula dinilai tidak baik dipandang sebagai masalah menuju situasi yang ideal. ${ }^{10}$ Dengan kata lain, menyelesaikan berbagai masalah yang ada, dengan melakukan perubahan-perubahan baik terhadap perilaku maupun situasi tertentu, itulah yang pada dasarnya dijadikan landasan mengapa suatu peraturan perundang-undangan diberlakukan. ${ }^{11}$

Salah satu jenis produk kosmetik yang dijual di media sosial, penulis mengambil produk kosmetik pemutih kulit atau bleacing. Bleacing merupakan pemutih kulit yang berbentuk cream dijual dalam kemasan botol. Produk bleacing ini menurut informasi bisa memutihkan kulit dalam beberapa minggu. Akan tetapi hasil pemakai produk bleacing tersebut tidak sesuai dengan infomasi yang diberikan untuk memutihkan kulit. Justru meberikan efek pada kulit timbulnya bintik-bintik yang merugikan konsumen. Hal tersebul malah timbulnya permasalahan baru terhadap konsumen yaitu ketidak jelasan informasi tentang produk yang ditawarkan. Kejelasan informasi atas produk kosmetik yang dijual dimedia sosial sangat penting bagi masyarakat atau konsumen, karena sangat berpengaruh bagi kesehatan dan keselamatan hidup mereka.

7Ahmadi Miru, Op. Cit, hlm.23.

8A.Z Nasution, Hukum Perlindungan Konsumen, Diadit Media, Jakarta, 2014, hlm. 78.

${ }^{9}$ Indriani Astuti, Banyak Produk Kosmetik Ilegal Berbahaya Dijual Secara Daring, https://mediaindonesia.com/read/detail/245093-banyak-produk-kosmetik-ilegal-berbahaya-dijual-secaradaring/ diunduh pada pukul 20:12 WIB tanggal 25 Januari 2020.

10 Wahyu Aji Chalifar, Konsumen dan Iklan: Studi tentang Iklan yang Menyesatkan di Facebook Twiter dan Instagram, Skripsi, Universitas Muhammaddiyah Surakarta, 2018, hlm. 2.

${ }^{11}$ Kelik Wardiono, Hukum Perlindungan konsumen: Aspek Subtansi Hukum, Struktur Hukum dan Kultur Hukum Dalam UU Nomor 8 Tahun 1999 Tentang Perlindungan Konsumen, Ombak, Yogjakarta, hlm. 1. 
Secara garis besar terdapat beberapa permasalahan yang terjadi dalam proses penjual produk kosmetik yang dijual melalui media sosial sebagaimana diatur dalam UUPK. Kosmetik telah menjadi suatu kebutuhan pokok yang digunakan setiap hari untuk menjaga penampilan baik laki-laki maupun perempuan. Kebutuhan akan produk-produk kosmetik tersebut merupakan peluang besar dalam sektor bisnis, terlebih lagi dengan adanya media sosial atau media online para pelaku usaha dapat menjual dan mempromosikan produk kosmetiknya dengan mudah. Namun tidak semua produk kosmetik yang dijual secara online telah memiliki izin edar dari BPOM (Badan Pengawas Obat dan Makanan).Hal ini disebabkan karena masih tingginya permintaan masyarakat terhadap kosmetik murah. Dengan begitu adanya celah yang dimanfaatkan para pelaku kejahatan dengan mengedarkan produk mereka secara online melalui akun media sosial yang beragam dan mengirimkannya melalui jasa ekspedisi atau memasarkannya ke toko-toko melalui penjual (seller). Dari permasalahan yang terjadi tentunya harus ada perlindungan hukum bagi konsumen karena mengingat konsumen merupakan pihak yang menanggung kerugian atau dapat dikatakan sebagai korban misalnya dalam kasus produk kosmetik bleacing (pemutih kulit) illegal yang mengandung bahan berbahaya.

Berdasarkan uraian diatas, maka dalam hal ini penulis tertarik untuk mengangkat menjadi topik pembahasan dalam metode penelitian ini dengan judul "Perlindungan Hukum Bagi Konsumen Pengguna Kosmetik Yang Dijual Melalui Media Sosial”.

\section{METODE PENELITIAN}

Jenis penelitian yang digunakan dalam penelitian adalah yuridis normatif. Metode penelitian hukum yuridis normatif ini juga biasa disebut dengan penelitian hukum doktriner atau juga disebut dengan penelitian ini hanya ditujukan pada peraturan-peraturan tertulis sehingga penelitian tersebut sangat erat hubungannya pada perpustakaan dikarenakan hukum normatif ini akan membutuhkan data-data yang bersifat sekunder pada perpustakaan. ${ }^{12}$ Disini penulis ingin mengetahui tanggung jawab pelaku usaha terhadap produk kosmetik yang dijual melalui media sosial dan perlindungan hukum bagi konsumen yang dirugikan oleh produk kosmetik yang dijual melalui media social

Pendekatan yang digunakan dalam peneltian ini adalah pendekatan undangundang (statute approach). Pendekatan perundang-undangan merupakan penelitian yang mengutamakan bahan hukum yang berupa peraturan perundang-undangan sebagai bahan acuan dasar dalam melakukan penelitian.

Penelitian dalam skripsi ini dari sudut sifatnya deskriptif adalah penelitian yang bertujuan untuk menggambarkan secara tepatsifat-sifat suatu individu, gejala atau penyebaran suatu gejala atau frekuensi adanya hubungan tertentu antara suatu gejala dengan gejala yang lain dalam masyarakat. ${ }^{13}$ Penelitian ini dari sudut bentuknya berupa penelitian diagnostik adalah suatu penelitian yang dilakukan guna mendapatkan dan menganalisis data tentang sebab-sebab timbulnya suatu gejala tertentu. ${ }^{14}$ Penelitian ini diharapkan dapat memberikan informasi secara jelas, lengkap, dan, sistematis dalam memaparkan dan menggambarkan mengenai alasan "Perlindungan Hukum Bagi Konsumen Pengguna Kosmetik Yang Dijual Melalui Media Sosial".

\footnotetext{
${ }^{12}$ Parta Setiawan, "Metode Penelitisn Hukum - Pengertian, Macam, Normatif, Empiris, Pendekatan, Data, Analisa, Para Ahli”, https://www.gurupendidikan.co.id/metode-penelitian-hukum/, diunduh pada pukul 20:34 WIB tanggal 6 Juli 2020.

13 Fakultas Hukum Universitas Malikussaleh, Buku Panduan Akademik, Unimal Press, Lhokseumawe,2015, hlm. 111-112.

${ }^{14}$ Soerjono Soekanto, Pengantar Penelitian Hukum, UI Press, Jakarta, 2004, hlm. 68.
} 


\section{PEMBAHASAN}

\section{Bentuk Perlindungan Hukum Bagi Konsumen Dalam Pembelian Produk Kosmetik Melalui Media Sosial}

Perlindungan konsumen adalah istilah yang dipakai untuk menggambarkan perlindungan hukum yang diberikan kepada konsumen dalam usahanya untuk memenuhi kebutuhannya dari hal-hal yang merugikan konsumen itu sendiri. UUPK menyatakan bahwa, perlindungan konsumen adalah segala upaya yang menjamin adanya kepastian hukum untuk memberikan perlindungan kepada konsumen. ${ }^{15}$ Upaya hukum untuk mencegah konsumen tidak dirugikan akibat kosmetik yang dijual oleh pelaku usaha melalui pemenuhan kewajiban untuk melaksanakan kegiatan usaha dengan beritikad baik. Pelaku usaha harus memberi kompensasi, ganti rugi dan/atau penggantian atas kerugian akibat penggunaan, pemakaian dan pemanfaatan barang yang diperdagangkan tidak sesuai dengan yang dijanjikan.

Salah satu sifat, sekaligus tujuan hukum itu adalah memberikan perlindungan kepada masyarakat. Oleh karena itu pengaturan perlindungan konsumen dapat dilakukan dengan ${ }^{16}$ menciptakan sistem perlindungan konsumen yang mengandung unsur keterbukaan akses dan informasi serta menjamin kepastian hukum, kemudian melindungi kepentingan konsumen pada khususnya dan kepentingan seluruh pelaku usaha, dengan meningkatkan kualitas barang dan pelayanan jasa, atau memberikan perlindungan kepada konsumen dari praktek usaha yang menipu dan menyesatkan, dan memadukan penyelenggaraan pengembangan dan pengaturan perlindungan konsumen dengan bidang-bidang perlindungan pada bidang-bidang lain.

Kesadaran hukum dan kepatuhan hukum, juga peran serta masyarakat terhadap upaya perlindungan konsumen, sedangkan dalam UUPK Pasal 29 ayat (1) dinyatakan bahwa "Pemerintah bertanggung jawab atas pembinaan penyelenggaraan perlindungan konsumen yang menjamin diperolehnya hak konsumen dan pelaku usaha serta dilaksakannya kewajiban konsumen dan pelaku usaha". Hukum perlindungan konsumen dalam banyak aspek berkorelasi erat dengan hukum-hukum perikatan perdata, tidak berarti hukum perlindungan konsumen semata-mata ada dalam wilayah hukum perdata. Ada aspek-aspek hukum perlindungan konsumen yang berada dalam hukum publik, terutama hukum perdata, hukum pidana, dan hukum administrasi negara. Jadi, tepatnya hukum perlindungan konsumen ada diwilayah hukum privat (perdata) dan wilayah hukum publik. ${ }^{17}$

Hukum dapat difungsikan untuk mewujudkan perlindungan dan sifatnya yang tidak sekedar adaptif dan fleksibel, melainkan juga prediktif dan antisipasif.Penegakan hukum dan keadilan harus menggunakan jalur pemikiran yang tepat dengan alat bukti dan barang buktiuntuk merealisasikan keadilan hukum dan isi hukum harus ditentukan oleh keyakinan etis dan adil tidaknya suatu perkara. Persoalan hukum menjadi nyata jika para perangkat hukum melaksanakan dengan baik serta memenuhi, menepati aturan yang dibakukan sehingga tidak terjadi penyelewangan aturan dan hukum yang dilakukan secara sistematis, artinya menggunakan kodifikasi dan unifikasi hukum demi terwujudnya kepastian hukum dan keadilan hukum. ${ }^{18}$ Kebutuhan perlindungan konsumen juga harus bersifat tidak berat sebelah dan harus adil, sebagai landasan penetapan hukum.

\footnotetext{
${ }^{15}$ Rosmawati, Op. Cit, hlm. 6.

${ }^{16}$ Husni Syawali dan Neni Sri Imaniyati, Op. Cit, hlm. 7.

${ }^{17}$ Shidarta, Hukum Perlindungan Konsumen Indonesia, Grasindo, Jakarta, 2004, hlm. 13.

${ }^{18}$ Ishaq, Dasar-Dasar Ilmu Hukum, Sinar Grafika, Jakarta, 2009, hlm. 43.
} 
Secara garis besar beberapa permasalahan yang terjadi pada proses transaksi media sosial, produk kosmetik bleacing (pemutih badan) dimana konsumennya hampir keseluruhan adalah wanita, dapat di liat dari konsumen tidak dapat langsung mengetahui, memeriksa dan melihat langsung barang yang akan dipesan kemudian tidak jelasnya informasi produk, status subjek hukum yakni pelaku usaha yang memproduksi tidak diketahui, tidak ada jaminan keamanan bertransaksi dan privasi serta penjelasan terhadap resiko-resiko yang berkenan dengan sistem yang digunakan, khususnya dalam hal pembayaran secara elektronik baik dengan credit card mapun electronic cash, dan pembebasan resiko yang tidak berimbang, karena umumnya terhadap jual beli di media sosial, pembayaran telah lunas dilakukan dimuka oleh konsumen, sedangkan barang belum tentu diterima atau akan menyusul kemudian, karena jaminan yang ada adalah jaminan pengiriman barang bukan penerimaan barang, kemudian transaksi yang bersifat lintas batas negara borderless, menimbulkan pertanyaan mengenai yuridisdiksi hukum negara mana yang sepatutnya diberlakukan. ${ }^{19}$

Jual beli kosmetik yang tidak memenuhi persyaratan melalui media sosial adalah cara jual beli yang dalam transaksinya menggunakan elektronik. Transaksi elektronik adalah perbuatan hukum yang dilakukan dengan menggunakan komputer, jaringan komputer, dan/atau media elektronik lainnya. Jual beli kosmetik melalui media sosial semakin hari semakin berkembang karena banyaknya pengguna sosial media hingga menjadi lahan bagi pelaku usaha untuk mengeruk keuntungan yang sebanyak-banyaknya tanpa mempertimbangkan standar produk yang ditawarkan. ${ }^{20}$

Pasal 9 UUITE berisi tentang "pelaku usaha yang menawarkan produk melalui sistem elektronik harus menyediakan informasi yang lengkap dan benar berkaitan dengan syarat kontrak, produsen, dan produk yang ditawarkan". Yang dimaksud dengan informasi yang lengkap dan benar dalam Pasal ini adalah informasi yang memuat identitas serta status subjek hukum dalam kopetensinya, baik sebagai produsen, pemasok, penyelenggara maupun perantara. Informasi lain yang harus dijelaskan dalam barang atau jasa yang ditawarkan adalah tentang nama, alamat dan deskripsi barang atau jasa. Namun dalam kenyataan yang ada dimasyarakat pelaku usaha menawarkan barangnya tanpa dilengkapi dengan informasi yang jelas seperti ketentuan Pasal 9.

Dalam melakukan transaksi jual beli di media sosial produk kosmetik pemutih badan perlu dilakukan dengan itikad baik. Itikad baik ini berlaku juga bagi penjual dan pembeli, seperti ketentuan Pasal 17 ayat (2) UUITE, bahwa:"Para pihak yang melakukan transaksi elektronik sebagaimana dimaksud pada ayat (1) wajib beritikad baik dalam melakukan interaksi dan/atau pertukaran informasi elektronik dan/atau dokumen elektronik selama transaksi berlangsung "

Pasal 28 UUITE berisi tentang "setiap orang dengan sengaja dan tanpa hak menyebarkan berita bohong dan menyesatkan yang mengakibatkan kerugian konsumen dalam transaksi elektronik". Dalam transaksi jual beli secara media sosial pelaku usaha dilarang untuk menyebarkan berita bohong bahkan menyesatkan yang akan merugikan konsumen. Sehingga

\footnotetext{
${ }^{19}$ Sri Arlina, Perlindungan Konsumen Dalam Transaksi Jual Beli Online Produk Kosmetik, Jurnal Law Review, Universitas Islam Riau, Volume 02, Nomor 01, April 2018, hlm. 325. file:///C:/Users/hp/Downloads/991-Article\%20Text-3408-1-10-20180416.pdf/ diunduh pada pukul 14:52 WIB tanggal 3 Februari 2021.

${ }^{20}$ IAIN Tulungaggung, Jual Beli kosmetik melalui instagram menurut hukum positifhttp://repo.iain-tulungagung.ac.id/10396/7/SKRIPSI\%20BAB\%204.pdf diunduh pada pukul 15:18 WIB tanggal 15 Januari 2021.
} 
dalam transksi ini harus pelaku usaha untuk jujur mengenai barang ditawarkan. ${ }^{21}$ Namun dalam kenyataannya pelaku usaha masih saja membohongi konsumen dengan memberikan nomor izin palsu yang sebenarnya tidak terdaftar pada BPOM dan bahkan memalsukan barang yang ditawarkan yang sebenarya ilegal seolah-olah seperti ilegal.

Pelaku usaha yang melakukan tindakan-tindakan yang melanggar peraturan yang telah ditetapkan sesuai dengan Pasal diatas akan mendapatkan sanksi dan harus mempertanggungjawabkan apa yang telah dilakukan sehingga bisa merugikan konsumen. Hal ini seperti yang telah ditetapkan dalam Pasal 28 ayat (2) UUITE "setiap orang memenuhi unsur sebagaimana dimaksud dalam Pasal 28 ayat (1) dan (2) dipidana dengan penjara paling lama 6(enam) tahun dan/atau denda paling banyak Rp. 1.000.000.000,00(satu miliar rupiah).

Perlindungan yang diawali dari konsumen media sosial yang menyikapi dengan lebih hati-hati dan teliti sebelum memesan produk kosmetik, memeriksa komposisi bahan yang terkandung aman atau tidak bagi kulit yang paling penting sudah lulus uji balai BPOM. Hal ini dikarenakan transaksi pembelian hanya dilakukan melalui media sosial dengan penggunaan transaksi elektronik, hanya melihat produk dari gambarnya saja tidak bisa di cobakan dan dirasakan bahannya. Transaksi secara online ataupun media sosial bagi pelaku usaha maupun konsumen masing-masing harus memiliki itikad baik dari awal. Perlindungan terhadap konsumen dalam transaksi jual beli di media sosial produk kosmetik bleacing (pemutih badan) yang mengandung zat berbahaya yang diberikan kepada konsumen oleh UUPK sangatlah jelas bahwa konsumen dilindungi hak-haknya. ${ }^{22}$

Saat ini tinggal bagaimana konsumen khususnya para wanita sebagai pemakai produk kosmetik harus lebih hati-hati dan waspada serta teliti dalam menggunakan bleching (pemutih badan). Ketidak berdayaan konsumen dalam menghadapi produsen jelas sangat merugikan kepentingan rakyat. Pada umumnya produsen berlindung dibalik standar contract atau perjanjian baku yang telah ditandatangani oleh kedua belah pihak, yakni antara konsumen dan produsen, ataupun melalui informasi semu yang diberikan oleh produsen kepada konsumen. ${ }^{23}$

Hal tersebut bukan menjadi persoalan global yang melanda seluruh konsumen di dunia. Menurut penulis timbulnya kesadaran konsumen ini telah melahirkan satu cabang baru ilmu hukum, yaitu hukum perlindungan konsumen, konsumen jangan mudah tergiur oleh iklan, rayuan dan serta tawaran instan di media sosial untuk memiliki tubuh yang putih dan bersih secara instan dari produk tersebut. Saatnya kita sebagai wanita menjadi konsumen yang cerdas, lebih pandai dan teliti untuk memilih dan menggunakan kosmetik, jangan mudah terayu dan mudah percaya terhadap produk kosmetik.

Berdasarkan uraian tersebut perlindungan konsumen berdasarkan UUPK dan UUITE segala upaya yang menjamin adayanya kepastian hukum agar terwujudnya tujuan perlindungan konsumen terhadap pelaku usaha yang menjual produk kosmetik melalui media sosial. Dimana perlindungan hukum kepada konsumen semakin penting disebabkan adanya kedudukan konsumen yang relatif lemah dibandingkan pelaku usaha. Sehingga terjadinya pelanggaran terhadap hak-hak konsumen disinilah peran perlindungan konsumen harus ditetapkan.

\footnotetext{
${ }^{21}$ Sovia Hasanah, Arti Berita Bohong Dan Menyesatkan Dalam UUITE, https://www.hukumonline.com/klinik/detail/ulasan/lt4eef8233871f5/arti-berita-bohong-danmenyesatkan-dalam-uu-ite/ diunduh pada pukul 11:23 WIB tanggal 21 Januari 2021.

${ }^{22} \mathrm{Ibid}, \mathrm{hlm} .328$.

${ }^{23}$ Diana Simanjuntak, Tinjauan Hukum Perlindungan Terhadap Perjanjian Kredit Bank, Jurnal Ilmu Hukum Legal Opinion, Edisi 1, Volume 4, Tahun 2016, hlm. 1. https://media.neliti.com/media/publications/149081-ID-tinjauan-hukum-perlindungan-konsumen-ter.pdf/ diunduh pada puku; 22:36 WIB tanggal 9 Februari 2021.
} 


\section{Bentuk Pelanggaran Pelaku Usaha Terhadap Produk Kosmetik Melalui Media Sosial}

Media sosial merupakan salah satu sarana penyampaian informasi yang mudah didapatkan masyarakat. Oleh karena itu, pelaku usaha dalam memasarkan produknya dapat menggunakan di media sosial, agar produk yang ditawarkan oleh pelaku usaha memiliki nilai jual yang tinggi dan ingin menarik perhatian masyarakat terkadang pelaku usaha menghalalkan segala cara. Salah satunya melalui media sosial yang memuat janji yang mengenai kegunaan dan manfaat produk yang sesuai dengan kebutuhan konsumen meskipun kenyataan nya bahwa produk tersebut kegunaan dan manfaatnya tidak sesuai dengan janji yang terdapat dalam produk tersebut. Sehingga produk tersebut telah membohongi konsumen atau masyarakat. ${ }^{24}$ Pelanggaran pelaku usaha atas hak-hak konsumen yang dilakukan dalam jual beli kosmetik dimedia sosial didasarkan karena banyaknya kewajiban-kewajiban pelaku usaha yang tidak dilaksanakan. Bentuk pelanggaran yang dilakukan oleh pelaku usaha yang merugikan konsumen atas produk kosmetik yang dijual melalui media sosial, hal ini berdasarkan Putusan MA No. 144/Pid.Sus/2019, Majelis Hakim berpendapat bahwa pelaku usaha tidak memiliki izin untuk membuat atau mengedarkan kosmetik tersebut, dan pelaku usaha juga menjelaskan bahwa cara mengedarkan kosmetik tersebut yaitu dengan menawarkan lewat online atau media sosial Facebook. Setiap sediaan farmasi dan alat kesehatan hanya dapat diedarkan setelah mendapat izin edar dari Menteri Kesehatan sebagaimana diatur dalam Pasal 106 Undang-Undang Nomor. 36 Tahun 2009, dan Pasal 98 ayat (2) menyebutkan bahwa setiap orang yang tidak memiliki keahlian dan kewenangan dilarang mengadakan, menyimpan, mengolah, mempromosikan, dan mengedarkan obat dan bahan yang berkhasiat obat. Hal ini juga karena ketidak pahaman konsumen atas hak-hak mereka yang mestinya bisa dituntut terhadap pelaku usaha. Pada dasarnya substansi Pasal 8 UUPK terdapat dua hal, yaitu larangan memproduksi barang dan/atau jasa, dan larangan memperdagangkan barang dan/atau jasa. Larangan yang dimaksud, hakikatnya untuk mengupayakan agar barang dan/atau jasa yang beredar di masyarakat merupakan produk layak edar, antara lain asal usul, kualitas sesuai dengan informasi pengusaha baik melalui label, etiket, iklan, dan lain sebagainya. ${ }^{25}$ Berbeda dengan produk-produk lainnya, terhadap barang-barang yang berupa sediaan farmasi mendapat perlakuan khusus, karena barang jenis tersebut jika rusak, cacat, bekas, atau tercemar maka dilarang untuk diperdagangkan, meskipun disertai dengan informasi yang lengkap dan benar atas barang tersebut.

Pelaranggaran pelaku usaha yang tertuju pada "produk" adalah untuk memberikan perlindungan terhadap kesehatan/harta konsumen dari penggunaan barang dengan kualitas yang di bawah standar atau kualitas yang lebih rendah dari pada nilai harga yang dibayar. Namun kenyataan yang ada dimasyarakat banyak kosmetik yang di edarkan oleh pelaku usaha tidak memuat informasi yang jelas, sehingga merugikan konsumen selaku pengguna barang yang dihasilkan oleh pelaku usaha. Dengan adanya perlindungan, maka konsumen tidak akan diberikan barang dengan kualitas yang lebih rendah daripada harga yang dibayarnya, atau yang tidak sesuai dengan informasi yang diperolehnya. Larangan yang bertuju pada produk adalah

\footnotetext{
${ }^{24}$ Lastini, Perbuatan Yang Dilarang Bagi Pelaku Usaha Menurut Undang-Undang Nomor 8 Tahun 1999 Tentang Perlindungan Konsumen, Jurnal Lex Privatum, Universitas Sam Ratulangi, Volume 4, Nomor 6, Juli, 2016, hlm. 68. https://media.neliti.com/media/publications/148870ID-perbuatan-yang-dilarang-bagi-pelaku-usaha.pdf diunduh pada pukul 14:58 WIB tanggal Februari 2021.

${ }^{25}$ Husni Syawali dan Neni Sri Imaniyati, Hukum Perlindungan Konsumen, MandarMaju, Bandung, 2000, hlm. 18.
} 
untuk memberikan perlindungan terhadap kesehatan/harta konsumen dari penggunaan barang dengan kualitas yang mungkin lebih rendah dari pada nilai harga yang dibayar. ${ }^{26}$

Sebagaimana diatur dalam Pasal 9 ayat (1) butir j UUPK menyatakan "Pelaku usaha dilarang menawarkan, mempromosikan, mengiklankan suatu barang dan/atau jasa secara tidak benar, dan/atau seolah-olah yang menggunakan kata-kata yang berlebihan, seperti aman tidak berbahaya, tidak mengandung risiko atau efek sampingan tanpa keterangan yang lengkap". Dan dalam Pasal 11 ayat (1) menyatakan "Pelaku usaha dalam hal penjualan yang dilakukan melalui cara obral atau lelang, dilarang mengelabui/menyesatkan konsumen dengan menyatakan barang dan/atau jasa tersebut seolah-olah telah memenuhi standar mutu tertentu". Dan dalam Pasal 13 ayat (1) menyatakan " Pelaku usaha dilarang menawarkan, mempromosikan atau mengiklankan obat, obat tradisional, suplemen makanan, alat kesehatan, dan jasa pelayanan kesehatan dengan cara menjanjikan pemberian hadiah berupa barang dan/atau jasa lain”. Dan dalam Pasal 17 ayat (1) butir c-d menyatakan "Pelaku usaha periklanan dilarang memproduksi iklan yang memuat informasi yang keliru, salah, atau tidak tepat mengenai barang dan/atau jasa, tidak memuat informasi mengenai risiko pemakaian barang dan/atau jasa".

Dengan demikian adanya larangan yang disebutkan dalam UUPK bagi pelaku usaha terhadap produk kosmetik yang dijual melalui media sosial memberikan perlindungan yang jelas terhadap konsumen yang membeli produk kosmetik melalui media sosial. Hal ini disebabkan karena pelaku usaha yang menawarkan produk melalui media sosial selaku konsumen berhak mendapatkan kompensasi dan ganti rugi dari pelaku usaha, adanya larangan yang ditentukan dalam UUPK terhadap pelaku usaha memberi perlindungan kepada konsumen sebagai adanya kepastian hukum.

\section{Akibat Hukum Bagi Pelaku Usaha Yang Telah Merugikan Konsumen Dalam Penjualan Produk Kosmetik Yang Dijual Melalui Media Sosial}

Sanksi hukum merupakan pelaksanaan dari sebuah perbuatan yang dilakukan sebagai bentuk terjadinya pelanggaran. ${ }^{27}$ Dalam pelaksanaan sengketa konsumen ada bermacam sanksi yang dapat diterapkan diantaranya adalah sanksi administratif. Atas setiap pelanggaran yang dilakukan pelaku usaha maka kepadanya dikenakan sanksi-sanksi hukum, baik sanksi administratif maupun sanksi pidana. Perbuatan yang bertentangan dengan tujuan menciptakan iklim usaha yang sehat dapat disebut sebagai perbuatan kejahatan. Maka terhadap pelanggaran atas ketentuan tentang hak dan kewajiban berdasarkan kelalaian pelaku usaha harus membayar ganti rugi kepada konsumen akibat kegiatan tertentu yang menyebabkan timbulnya kerugian terhadap konsumen. ${ }^{28}$

Sanksi administratif yang di kenakan kepada pelaku usaha yang melanggar Pasal 60 Ayat (2) UUPK berupa ganti rugi paling banyak Rp. 200.000 .000 (dua ratus juta rupiah), dan yang berwenang mengadili atau memberikan sanksi administratif ini adalah Badan Penyelesaian Sengketa Konsumen ( selanjutnya disebut BPSK). Ganti kerugian terserbut merupakan bentuk pertanggunggugatan terbatas, sehingga secara keseluruhan dapat dikatakan bahwa ganti kerugian yang dianut dalam UUPK.

${ }^{26}$ Universitas Pansundan Bandung, Tinjauan Pustaka Tentang Perlindungan Konsumen Dan Badan Pengawasan Obat Dan Makanan, http://repository.unpas.ac.id/46390/1/10-\%20BAB\%20II.pdf/ diunduh pada pukul 22:31 WIB tanggal 11 Januari 2021.

${ }^{27}$ Rosmawati, Op. Cit, hlm. 91.

${ }^{28}$ Ibid, hlm. 92. 
Sedangkan sanksi pidana dalam Pasal 61 UUPK penentuan pidana dapat dilakukan terhadap pelaku usaha atau pengurusnya yang melanggar Pasal 8,9 dan Pasal 10, Pasal 133, Pasal 15 Dan Pasal 17 dipidana dengan penjara paling lama 5(lima) tahun atau pidana denda paling banyak Rp. 2. 000.000.000 (dua miliar rupiah). Suatu peristiwa atau perbuatan yang bertentangan dengan asas-asas hukum merupakan suatu perbuatan melawan hukum. Hukuman baru bisa dijatuhkan kepada pelaku pidana apabila tindak pidana yang dilakukannya memenuhi syarat-syarat atau unsur-unsur yang ada pada ketentuan hukum positif.

Pasal 28 UUITE berisi tentang "setiap orang dengan sengaja dan tanpa hak menyebarkan berita bohong dan menyesatkan yang mengakibatkan kerugian konsumen dalam transaksi elektronik". Dalam transaksi jual beli secara media sosial pelaku usaha dilarang untuk menyebarkan berita bohong bahkan menyesatkan yang akan merugikan konsumen. Sehingga dalam transksi ini harus pelaku usaha untuk jujur mengenai barang ditawarkan. ${ }^{29}$ Namun dalam kenyataannya pelaku usaha masih saja membohongi konsumen dengan memberikan nomor izin palsu yang sebenarnya tidak terdaftar pada BPOM dan bahkan memalsukan barang yang ditawarkan yang sebenarya ilegal seolah-olah seperti ilegal.

Pelaku usaha yang melakukan tindakan-tindakan yang melanggar peraturan yang telah ditetapkan sesuai dengan Pasal diatas akan mendapatkan sanksi dan harus mempertanggungjawabkan apa yang telah dilakukan sehingga bisa merugikan konsumen. ${ }^{30}$ Hal ini seperti yang telah ditetapkan dalam Pasal 28 ayat (2) UUITE "setiap orang memenuhi unsur sebagaimana dimaksud dalam Pasal 28 ayat (1) dan (2) dipidana dengan penjara paling lama 6(enam) tahun dan/atau denda paling banyak Rp. 1.000.000.000,00(satu miliar rupiah).

Tanggung gugat produk merupakan terjemahan bebas dalam bahasa Indonesia yang secara populer sering disebut dengan product liability adalah suatu konsepsi hukum yang intinya dimaksudkan memberikan perlindungan kepada konsumen yaitu dengan jalan memberikan perlindungan konsumen dari beban untuk membuktikan bahwa kerugian konsumen timbul akibat kesalahan dalam proses produksi dan sekaligus ganti rugi. Pada dasarnya konsep tanggung gugat produk ini secara umum tidak jauh berbeda dengan konsepsi tanggung jawab sebagaimana diatur dalam ketentuan Pasal 1365 dan Pasal 1865 KUHPerdata. ${ }^{31}$

Perbedaannya adalah bahwa tanggung jawab produsen untuk memberikan ganti rugi diperoleh, setelah pihak yang menderita kerugian dapat membuktikan bahwa cacatnya produk tersebut serta kerugian yang timbul merupakan akibat kesalahan yang dilakukan produsen. Perbedaan lain, yaitu bahwa ketentuan ini tidak secara tegas mengatur pemberian ganti rugi atau beban pembuktian kepada konsumen, melainkan kepada pihak manapun yang mempunyai hubungan hukum dengan produsen, apakah sebagai konsumen, sesama produsen penyalur, pedagang atau instansi lain, sehingga sebagai suatu konsep, materi tanggunggugat produk yang

\footnotetext{
${ }^{29}$ Dimas Hutomo, Pasal Untuk Menjerat Penyebar Hoax, https://www.hukumonline. com/klinik/detail/ulasan/lt5b6bc8f2d737f/pasal-untuk-menjerat-penyebar-ihoax-i/diunduh pada pukul 23:15 WIB tanggal 9Januari 2021.

${ }^{30}$ Marcelo Leonardo Tuela, Upaya Hukum Perlindungan Konsumen Terhadap Barang Yang Diperdagangkan,https://core.ac.uk/download/pdf/326774515.pdf/ diunduh pada pukul 10:11 WIB tanggal 4 Desember 2020.

${ }^{31}$ Hizkia David Lumolos, Upaya Hukum Konsumen Kepada Pelaku Usaha Akibat Barang Yang Digunakan Dalam Keadaan Rusak Menurut Undang-Undang Nomor 8 Tahun 1999 Tentang Perlindungan Konsumen, Jurnal Lex Privatum, Universitas Sam Ratulangi, Volume 4, Nomor 8, Oktober, 2018, hlm. 63. file:///C:/Users/hp/Downloads/22861-46651-1-SM\%20(1).pdf / diunduh pada pukul 16:33 WIB tanggal 7 Desember 2020.
} 
pada hakikatnya termasuk doktrin hukum yang masih baru merupakan salah satu upaya untuk memperkaya khasanah dalam sistem hukum yang selama ini berlaku di Indonesia. ${ }^{32}$

Dalam UUPK seharusnya tidak boleh secara sepihak menentukan klausula yang merugikan konsumen, termasuk maksimal tanggung jawabnya. Jika ada pembatasan, mutlak harus berdasarkan pada peraturan perundang-undangan yang jelas. Untuk itu, menurut penulis tanggung jawab pelaku usaha atas produk yang merugikan konsumen sangat perlu diperhatikan dan perlu diperhatikan dan perlu perhatian dari pemerintah yang berwenang demi tercapainya kepuasan konsumen dan keuntungan dari pelaku usaha. Dan apabila terjadi kerugian pada konsumen yang disebabkan oleh produk dari pelaku usaha, maka sudah sepantasnya pelaku usaha memberikan ganti kerugian kepada konsumen, yaitu penggantian dengan barang dan/atau jasa yang sama dan penggantian dengan sejumlah uang.

\section{Penyelesaian Sengketa Bagi Konsumen Yang Telah Dirugikan Oleh Pelaku Usaha Dalam Penjualan Produk Kosmetik Melalui Media Sosial}

Penyelesaian sengketa merupakan hal yang wajar apabila dalam hubungan perdagangan pada suatu saat mengalami pertikaian atau konflik, hal ini pada hakekatnya merupakan salah satu bentuk dari interaksi sosial dalam kehidupan bermasyarakat. Konflik akan berkembang menjadi sengketa apabila pihak yang menimbulkan kerugian pada pihak lain. Kata sengketa mestinya tidak hanya bersifat merusak dan merugikan, melainkan membangun, menarik atau menantang serta dinamis sebagai katalisator perubahan. ${ }^{33}$ Sengketa konsumen adalah setiap perselisihan antara konsumen dan penyedia produk konsumen (barang dan/atau jasa) dalam hubungan hukum satu sama lain, mengenai produk konsumen tertentu. ${ }^{34}$

Dalam kegiatan jual beli media sosial terdapat hubungan saling membutuhkan antara pelaku usaha dengan konsumen, baik berupa pelaku usaha dan konsumen barang maupun jasa. Kepentingan usaha dalam memperoleh keuntungan semaksimal mungkin dari transaksi dengan konsumen, sedangkan di sisi lain, konsumen berkepentingan untuk memperoleh kepuasan melalui pemenuhan kebutuhannya terhadap produk. Dengan kata lain, konsumen mempunyai hak untuk mendapatkan kualitas yang diinginkan. Untuk melindungi atau memperdayakan konsumen sangat diperlukan adanya campur tangan pemerintah dan/atau negara melalui penetapan sistem perlindungan hukum terhadap konsumen. ${ }^{35}$

UUPK menetapkan dua cara penyelesaian yaitu diluar pengadilan dan melalui pengadilan. Penyelesaian sengketa di luar pengadilan, yaitu dengan proses membuat pengaduan ataun gugatan atas kerugian yang dilakukan pelaku usaha ke BPSK atau Lembaga Perlindungan Konsumen Swadaya Masyarakat (selanjutnya disebut LPKSM). Dari pengaduan tersebut BPSK wajib mengeluarkan putusan paling lambat dalam waktu 21 (dua puluh satu) hari kerja setelah gugatan diterima. Penyelesaian sengketa melalui pengadilan, yaitu dengan proses konsumen yang merasa dirugikan melapor kepada pihak yang berwajib yaitu kepada polisi untuk ditindaklanjuti sebagaimana pada proses penyelesaian sengketa di pengadilan pada umumnya. Penyelesaian melalui jalur ini mengacu pada ketentuan tentang peradilan umum yang berlaku di

\footnotetext{
${ }^{32}$ Ibid, hlm. 64.

${ }^{33}$ Yusuf Shofie, Penyelesaian Sengketa Konsumen Menurut Undang-Undang Perlindungan Konsumen Teori\&Praktik Penegakan Hukum, PT Citra Aditya Bakti, Bandung, 2003, hlm. 12.

${ }^{34}$ A.Z Nasution, Op. Cit, hlm. 178.

${ }^{35}$ Rosmawati, Op. Cit, hlm. 108.
} 
Indonesia. ${ }^{36}$ Pasal 45 ayat (1) UUPK menyatakan "setiap konsumen yang dirugikan dapat menggugat pelaku usaha melalui lembaga yang bertugas menyelesaikan sengketa antara konsumen dan pelaku usaha atau melalui peradilan yang berada dilingkungan peradilan umum“.

Undang-Undang Nomor 30 Tahun 1999 tentang Arbitrase dan Alternatif Penyelesaian Sengketa, Pasal 1 ayat (10) menyebutkan bahwa alternatif penyelesaian sengketa adalah lembaga penyelesaian sengketa atau beda pendapat melalui produser yang disepakati para pihak, yakni penyelesaian di luar pengadilan dengan cara konsultasi, mediasi, konsiliasi, atau penilaian ahli.

Penyelesaian suatu sengketa perdata diluar peradilan umum yang didasarkan pada perjanjian arbitrase yang dibuat oleh para pihak yang bersengketa sudah sejak lama dikenal di indonesia. Bahkan telah dibentuk Badan Arbitrase Nasional Indonesia (BANI) sejak 30 Nopember 1977, Berdasarkan surat Keputusan Kamar Dagang dan Industri (KADIN) Nomor SKEP/12/DPH/1997. ${ }^{37}$

Penyelesaian sengketa melalui peradilan arbitrase ini dapat dilakukan oleh

para pihak yang bersengketa, jika para pihak tersebut telah mencantumkan klausul arbitrase dalam perjanjian yang menjadi pokok sengketa atau mengadakan perjanjian arbitrase setelah timbulnya sengketa diantara mereka. Kelebihan penyelesaian sengketa melalui arbitrase ini karena putusannya langsung final dan mengikat para pihak.Putusan arbitrase ini memiliki kekuatan eksekutorial, sehingga apabila pihak yang dikalahkan tidak memenuhi putusan secara sukarela, maka pihak yang menang dapat memintaeksekusi ke pengadilan. ${ }^{38}$

Sebagai alternatif penyelesaian sengketa konsumen,penyelesaian sengketa konsiliasi ini memiliki banyak kesamaan dengan arbitrase, dan juga menyerahkan kepada pihak ketiga untuk memberikan pendapatnya tentang sengketa yang disampaikan oleh para pihak. Walaupun demikian, pendapat dari konsiliator tersebut tidak mengikat sebagaiman mengikatnya putusan arbitrase. Ketidak terikatan para pihak terhadap pendapat yang diajukan oleh konsiliator mengenai sengketa yang dihadapi oleh para pihak tersebut, menyebabkan penyelesaiannya sangat tergantung pada kesukarelaan para pihak. ${ }^{39}$

Penyelesaian sengketa melalui mediasi harus didahului dengan kesepakatan para pihak untuk menyelesaikan permasalahan melalui mediasi. Kesepakatan ini dapat dilakukan sebelum timbulnya sengketa, yaitu dengan memasukkan sebagai klausula perjanjian, atau setelah timbul sengketa kemudian para pihak membuat kesepakatan untuk menyerahkan penyelesaiannya melalui mediasi.

Dua cara tersebut lebih menguntungkan jika cara pertama yang tempuh, karena para pihak yangbersengketa sejak awal telah menginginkan mediasi, sehingga kemungkinan berhasilnya proses mediasi lebih besar. ${ }^{40}$ Mediasi merupakan cara penyelesaian sengketa yang

${ }^{36}$ Herni Aning Subandini, Simak Mekanisme Penyelesaian Sengketa Konsumen Diindonesia, https://bahasan.id/simak-mekanisme-penyelesaian-sengketa-konsumen-di-indonesia/ diunduh pada pukul 21:30 WIB tanggal 15 Desember 2020.

${ }^{37}$ Ahmadi Miru, Op. Cit, hlm. 159.

${ }^{38}$ Ibid,hlm. 160.

${ }^{39} \mathrm{Ibid}$, hlm. 162-163.

${ }^{40}$ Winner Sitorus, Aspek-Aspek Hukum Penyelesaian Sengketa Bisnis Internasional Melalui Mediasi Sebagai Alternatif Penyelesaian Sengketa, Tesis, UI, Jakarta, 1998, hlm. 125. (dikutip dalam buku Ahmadi Miru, Prinsip-Prinsip Perlindungan Bagi Konsumen Diindonesia). 
fleksibel dan tidak mengikat serta melibatkan pihak netral, yaitu mediator, yang memudahkan egosiasi antara para pihak/membantu mereka dalam mencapai kompromi/kesepakatan. ${ }^{41}$

Berdasarkan Pasal 46 UUPK, yang dapat mengajukan gugatan dalam sengketa perlindungan konsumen atas pelanggaran pelaku usaha adalah dapat dilakukan oleh konsumen yang dirugikan yang mempunyai kepentingan yang sama dengan memenuhi syarat, yaitu berbentuk badan hukum, yang dalam anggaran dasarnya menyebutkan dengan tegas bahwa tujuan didirikannya organisasi tersebut adalah untuk kepentingan perlindungan konsumen dantelah melaksanakan kegiatan sesuai anggaran dasar. Serta pemerintah atau instansi yang terkait apabila barang yang dimanfaatkan mengakibatkan kerugian materi yang besar terhadap konsumen.

Konsumen bersifat pasif dan biasanya berekonomi lemah dimana pelaku usaha memiliki pengetahuan yang lebih tentang informasi atas keadaan produk yang dipasarkan mereka padaumumnya berada pada posisi lebih kuat. Posisi tersebut baik dari segi ekonomi maupun dalam posisi negosiasi,kepentingan antara konsumen dan pelaku usaha juga sangat berbeda. Jika ada keluhan terhadap produknya, pelaku usaha akan mengupayakan penyelesaian tertutup. ${ }^{42}$

Sementara itu, konsumen memilik kepentingan agar penyelesaian dilakukan lewat saluran umum supaya tuntas. ${ }^{43}$ Setiap konsumen yang dirugikan, dapat mengajukan pengaduan dengan dilengkapi bukti-bukti yang ada, selanjutnya pengaduan tersebut akan diteliti dan diselidiki apabila mengandung unsur-unsur yang melanggar ketentuan undang-undang maka dapat ditindaklanjuti dengan upaya penyelesaian. Konsumen langsung melaporkan dan menggugat pelaku usaha, bentuk penyelesaian besarnya ganti rugi diserahkan kepada pada pihak dengan kesepakatan dan syarat bahwa untuk tercapainya penyelesaian sengketa, kedua belah pihak harus mempunyai kemauan dan etika. Karena dizaman saat ini banyak konsumen hanya mengeluh dan tidak memberanikan diri untuk mengadu atau melapor kepihak yang berwenang atas produk kosmetik yang dijual melalui media sosial karena kerugian tersebut.

Penyelesaian sengketa secara khusus oleh UUPK memberikan berbagai manfaat bagi semua kalangan, bukan saja konsumen tetapi juga bagi pelaku usaha sendiri, bahkan juga pemerintah. Manfaat bagi yang dirasakan konsumen, mendapat ganti rugi atas kerugian yang diderita sehingga melindungi konsumen lain agar tidak mengalami kerugian yang sama, karena satu orang melapor maka sejumlah orang lainnya akan dapat tertolong. Adanya Complain yang diajukan konsumen melalui ruang publik dan mendapat liputan media masa akan mendorong tanggapan yang lebih positif yang menunjukkan sikap kepada masyarakat pelaku usaha lebih memperhatikan kepentingan konsumen.

Konsumen yang bermasalah terhadap produk yang dikonsumsi akan dapat memperoleh haknya secara lebih mudah dan efisien melalui BPSK. Selain itu bisa juga menjadi sebuah akses untuk mendapatkan informasi dan jaminan perlindungan hukum yang sejajar baik untuk konsumen maupun pelaku usaha. ${ }^{44}$

\footnotetext{
${ }^{41}$ Mulyana W.Kusuma, Should Court-Annexed Alternative Dispute Resolution Mechanisme Mandatory, Jurnal Hukum Ilmiah Ilmu Hukum Era Hukum, Nomor 1 Tahun 1994, hlm. 5. (dikutip dalam buku Ahmadi Miru, Prinsip-Prinsip Perlindungan Bagi Konsumen Diindonesia).

${ }^{42}$ Aulia Muthiah, Tanggung Jawab Pelaku Usaha Kepada Konsumen Tentang Keamanan Pangan Dalam Persfektif Hukum Perlindungan Konsumen, file://C:/Users/hp/Downloads/712Article\%20Text-876-1-10-20180220.pdf / diunduh pada pukul 01:14 WIB tanggal 10 Februari, 2021.

${ }^{43}$ Rosmawati, Op. Cit, hlm. 110.

${ }^{4}$ Ibid
} 
Dalam menangani dan mengatur permasalahan konsumen, BPSK memiliki kewenangan untuk melakukan pemeriksaan atas kebenaran laporan dan keterangan dari pihak yang bersengketa, dan bukti lain oleh konsumen dan pengusaha dengan mengikat penyelesaian akhir. Tugas utama BPSK menangani permasalahan konsumen melalui mediasi,konsiliasi, arbitrase, serta konsultasi konsumen dalam hal perlindungan konsumen yang mengontrol penambahan dari bagian-bagian standarisasi sehingga memberikan sanksi adminstrasi terhadap pengusaha yang menyalahi aturan. ${ }^{45}$

Dengan demikian penulis mengambil penyelesaian sengketa secara cepat terhadap tuntutan ganti kerugian oleh konsumen terhadap pelaku usaha telah dilakukan diindonesia. Hal ini dapat diliat dalam UUPK yang memberikan kemungkinan konsumen untuk mengajukan penyelesaian sengketa diluar pengadilan, yaitu melalui BPSK yang putusannya dinyatakan final dan mengikat, sehingga tidak dikenal lagi upaya hukum banding maupun kasasi dalam penyelesaian sengketa konsumen tersebut. Oleh karena itu konsumen harus mengatasi dan menyelesaikan permasalahan tanpa harus melakukan pengurusan dipusat. Hal ini dimaksudkan untuk memberikan kemudahan kepada konsumen untuk melakukan upaya hukum.

\section{KESIMPULAN}

1. Perlindungan hukum terhadap konsumen berdasarkan UUPK belum cukup memadai untuk melindungi hak-hak konsumen. Dan pelaksanannya belum cukup efektif, karena masih ditemukan pelaku usaha yang menjual kosmetik yang ilegal yang mengandung bahan berbahaya di media sosial. Belum sepenuhnya hak-hak konsumen terpenuhi dan dilindungi dengan adanya hukum perlindungan konsumen. Dengan ditetapkanya UUPK, hak-hak konsumen Indonesia mendapatkan perlindungan hukum. Perlindungan yang diawali dari konsumen di media sosial agar menyikapi dengan lebih hati-hati dan teliti sebelum memesan produk kosmetik, harus memeriksa aman atau tidaknya. Hal ini dikarnakan transaksi pembelian hanya dilakukan melalui media sosial dengan pengguna transaksi elektronik, hanya melihat produk dari gambarnya saja tidak bisa dicobakan dan dirasakan bahannya. Transaksi secara media sosial bagi pihak pelaku usaha maupun konsumen masingmasingharus memiliki itikad baik dari awal.

2. Akibat hukum bagi pelaku usaha yang telah merugikan konsumen, pelaku usaha mendapatkan sanksi yaitu mengganti kerugian terhadap konsumen. Sanksi yang dapat diterapkan diantaranya adalah sanksi administratif. Atas setiap pelanggaran yang dilakukan pelaku usaha, maka pelaku usaha mengganti kerugian terhadap konsumen salah satunya membayar ganti kerugian yang dialami konsumen, baik sanksi administratif maupun sanksi pidana. Perbuatan yang bertentangan dengan tujuan menciptakan iklim usaha yang sehat dapat disebut sebagai perbuatan kejahatan. Maka terhadap pelanggaran atas ketentuan tentang hak dan kewajiban berdasarkan kelalaian pelaku usaha harus membayar ganti rugi kepada konsumen akibat kegiatan tertentu yang menyebabkan timbulnya kerugian terhadap konsumen.

\section{SARAN}

1. Disarankan kepada pelaku usaha dalam usahanya perlu menunjukkan itikad baik serta harus mencari tahu konsekuensinya apa yang diperoleh dalam melakukan usahanya. Pelaku usaha 
juga harus memperhatikan hak-hak konsumen sertakewjibannya, pelaku usaha harus berusaha memenuhinya.Pelaku usaha wajib memberi informasi yang jelas terkait kosmetik yang dijual melalui media sosial, agar konsumen tidak tertipu daya oleh kosmetik abal-abal dengan harga yang terbilang lemayan murah.

2. Disarankan kepada konsumen harus berhati-hati dan harus cerdik dalam membeli produk kosmetik melalui media sosial, jangan mudah tergiur oleh produk kosmetik yang instan dan cepat mendapatkan hasil yang memuaskan. Lihat terlebih dahulu komposisi dan lebel yang jelas, belum tentu bahan yang digunakan dalam komposisi kosmetik aman, sehingga mengakibatkan yang fatal. 


\section{DAFTAR PUSTAKA}

Ahmadi Miru, Prinsip-prinsip Perlindungan Hukum Bagi Konsumen. Di Indonesia, PT RajaGrafindo Persada, Jakarta, 2011.

Amiruddin , Zainal Asikin, Pengantar Metode Penelitian Hukum, Raja Grafindo Persada, Jakarta, 2004.

Az. Nasution. Hukum Perlindungan Konsumen, Diadit Media, Jakarta, 2014.

Fakultas Hukum Universitas Malikussaleh, Buku Panduan Akademik, Unimal Press, Lhokseumawe, 2015.

Firman Tumantara, Hukum Perlindungan Konsumen Filosofi Perlindungan Konsumen Dalam Persfektif Politik Hukum Negara Kesejahteraan, Setara Press, Malang.

Hadjon, Phillipus M, Perlindungan Hukum Bagi Rakyat Indonesia, Bina Ilmu, Surabaya, 1987.

Husni Syawali dan Neni Sri Imaniyati, Hukum Perlindungan Konsumen, Mandar Maju, Bandung.

Janus Sidabolok, Hukum Perlindungan Konsumen Di Indonesia, Aditya Bakti, Bandung, 2010.

Kelik Wardiono, Hukum Perlindungan konsumen: Aspek Subtansi Hukum, Struktur Hukum Dan Kultur Hukum Dalam UU Nomor 8 Tahun 1999 Tentang Perlindungan Konsumen, Ombak, Yogjakarta, 2017.

Lamuel W. Dowdy,et.al, Prepared by Consumer Dispute Resolution Program Staff Attorneys, Federal Trade Commission-Division of Product Reliability, Washington, D.C, (dikutip dalam buku Ahmadi Miru, Perlindungan Konsumen di Indonesia ).

Philip Kotler, Principles of Marketing, Erlangga, Jakarta, 2000.

Peter Mahmud Marzuki. Penelitian Hukum, Kencana Prenada Media, Jakarta, 2005.

Rosmawati, Pokok-Pokok Perlindungan Konsumen, Prenamedia Group, Depok, 2018

Soekanto, Soerjono, Pengantar Penelitian Hukum, UI Press, Jakarta, 1984.

Shidarta, Hukum Perlindungan Konsumen Indonesia, Grasindo, Jakarta, 2004.

Ishaq, Dasar-Dasar Ilmu Hukum, Sinar Grafika, Jakarta, 2009.

Yusuf Shofie. Perlindungan Konsumen Dan Instrumen-Instrumen Hukumnya, PT.Citra Aditya Bakti, Bandung

Keputusan Kepala Badan Pengawas Obat Dan Makanan Republik Indonesia Nomor: HK.00.05.41745 Tahun 2003 tentang Kosmetik, BPOM RI.

Peraturan Mentri Kesehatan Republik Indonesia Nomor 1175/MENKES/PER/VIII/2010 tentang Izin Produksi Kosmetik.

Peraturan Pemerintah Republik Indonesia Nomor 58 Tahun 2001 Tentang Pembinaan dan Pengawasan Penyelenggaraan Perlindungan Konsumen.

Undang-Undang Nomor 8 Tahun 1999 Tentang Perlindungan Konsumen.

Undang-Undang Nomor 11 Tahun 2008 Tentang Informasi dan Transaksi Elektronik

Amira Eka Anandhita, Tinjauan Hukum Islam Dan Undang-undang No.8 Tahun 1999 Tentang Perlindungan Konsumen Terhadap Transaksi Jual Beli Online Kosmetik Di Cosmeticsworldwide, Skripsi, Universitas Islam Negeri Sunan Ampel, 2019.

Arliwaman, Perlindungan Hukum Terhadap Konsumen Pengguna Kosmetik Yang Memiliki Kode Izin Edar Palsu (Fiktif) Ditinjau Dari Undang-Undang Nomor 8 Tahun 1999 Tentang Perlindungan Konsumen, Skripsi, Fakultas Hukum Universitas Lampung, 2019.

Firman Tumantara, Hukum Perlindungan Konsumen Filosofi Perlindungan Konsumen Dalam Persfektif Politik Hukum Negara Kesejahteraan, Setara Press, Malang.

Lois Yulius, Tanggung Jawab Pelaku Usaha Atas Produk Yang Merugikan Konsumen, Jurnal Lex Privatum, Volume 1, Nomor 3, Juli 2013.

Monarisa Salsabila, Perlindungan Konsumen Terhadap Produk Kosmetik Yang Dijual Secara Online Di Kota Banda Aceh, Skripsi, Banda Aceh, Universitas Syiah Kuala.

Mulyana W. Kusuma, Should Court-Annexed Alternative Dispute Resolution Mechanisme Mandatory, Jurnal Hukum Ilmiah Ilmu Hukum Era Hukum, Nomor 1 Tahun 1994.

Septa Diansari, Tanggung Jawab Pelaku Usaha Terhadap Peredaran Produk Kosmetik Yang Tidak Terdaftar Pada Badan Pengawasan Obat dan Makan, Skripsi, Universitas Sriwijaya Indralaya, 2018. 
Sri Arlina, Perlindungan Konsumen Dalam Transaksi Jual Beli Online Produk Kosmetik, UIR Law Review, Volume 02, Nomor 01, April 2018.

Winner Sitorus, Aspek-Aspek Hukum Penyelesaian Sengketa Bisnis Internasional Melalui Mediasi Sebagai Alternatif Penyelesaian Sengketa, Tesis, UI, Jakarta, 1998.

Zakiah, Pelaksanaan Pengawasan Dinas Perindustrian Dan Perdagangan Terhadap Penerapan Ukuran, Takaran, Timbangan Dan Perlengkapannya (Uttp) Pada Pedagang Pasar Cik Puan Di Pekanbaru, Tesis, Universitas Islam Negeri Sultan Syarif Kasim Riau, 2014. 